\title{
Environmental solutions of recovery of Amazonian forest mining operations
}

\author{
R. M. Longo ${ }^{1}$, A. Í. Ribeiro ${ }^{2}$, W. J. de Melo $^{2}$ \& A. C. Demanboro ${ }^{1}$ \\ ${ }^{1}$ Pontifícia Universidade Católica, PUC-Campinas, Brazil \\ ${ }^{2}$ Brazil University State of São Paulo, UNESP, Brazil
}

\begin{abstract}
In order for the projects of recovery of degraded areas to be successful, it is necessary to have a perfect recovery of the soil where the revegetation will be implanted as an initial action in the recovery of the whole process. The use of native forest species fully adapted to these types of terrain is another aspect of great importance, once the non-selection of these species, even if abundant in the surrounding areas, as it is in our case, implies great mortality of individuals during the planting and their low fixation during the process. The establishment of a monitoring program that contemplates the advancements obtained in the soil, the vegetation and the return of wild animals also collaborate in the evaluation of the success of the process. And, finally, the effective participation of the mining company, accepting and applying the techniques tested and indicated by research, even if, initially, the return time is longer than expected, also guarantees the success of the process. The mining company not only implemented a partnership with important universities in Brazil to obtain solutions for the environmental problems but also applied the developed techniques and the monitoring program. In the present work, we have attempted to summarize important aspects to evaluate the advancements in the rehabilitation plan for those areas, being here presented some results of the monitoring of areas under different levels of recovery, in accordance with the techniques adopted. Biological parameters of the soil were used to verify the efficiency of these different techniques in the recovery process. This work is part of the monitoring program of areas in rehabilitation by the mining company, implemented as of 1999 and in partnership with universities. The microbial activity was determined through the quantification of the carbon and nitrogen microbial biomass (BMC and $\mathrm{BMN}$ ) and the activity of the dehydrogenase
\end{abstract}


evaluated in the mining floor and tailing areas in different levels of soil preparation and planting of native species. The analysis of the parameters studied revealed that the preparation of the soil, following the three years proposed by the methodology, was important for the success in establishing the rehabilitation process. Some of the areas analyzed already show some parameters with values close or superior to those found in the capoeira (secondary forest), the latter being the non-treated area.

Keywords: recovery, degraded area.

\section{Introduction}

The recovery of areas degraded by mining activities comprehends a set of techniques that range from the understanding of the degraded environment to the application of techniques researched and adjusted to the new formed environment. After some years of work, researches have been implemented and some techniques were evaluated, aiming at the rehabilitation of an area degraded by tin mining in the state of Rondônia/Brazil. According to the research conducted in the area, it is possible to observe that a fundamental aspect in the rehabilitation of areas degraded by mining, in general, is the knowledge about the soil where that recovery must be conducted. The specific procedures in the rehabilitation of those areas depend essentially on the physical, chemical, biological and mineralogical properties of the soil, which must present conditions for the adequate development of the plants (Fontes [1]). Thus it is understood that for the projects of recovery of degraded areas to obtain success there must be a perfect recovery of the soil where the revegetation will be implemented as an initial action in the recovery of the whole process. The use of native forest species fully adapted to these types of terrain, that presents serious biological, physical and chemical problems, is another aspect of great importance, since the non-selection of these species, even if existent in abundance in the surrounding areas, as it is our case, implies large mortality of individuals during the planting and the low fixation of those during the process. The establishment of a monitoring program that contemplates the advances obtained in the soil, vegetation and return of wild animals also collaborates to evaluate the success of the process. Finally, the effective participation of the mining company, accepting and applying the techniques tested and indicated by the researches, even if the return time is longer than the expected, also guarantees the success of the process. Brascan Brasil not only implemented a partnership with important universities in Brazil to obtain solutions for the environmental problems, but also applies the developed techniques and the monitoring program.

Models for the recovery of degraded soils must be based on technologies that are capable of improving them by means of the input of organic matter with low $\mathrm{C} / \mathrm{N}$ relation (Franco et al. [2]) permitting the reestablishment of life in the soil.

This work aims to present some results of the monitoring of areas under different levels of recovery, according to the presented technique. 


\section{Material and methods}

The soil samples were collected in the National Forest (FLONA) of Jamari, administered by the Brazilian Institute of Environment and Renewable Mineral Resources - IBAMA and located $90 \mathrm{~km}$ outside the city of Porto Velho - RO, in the municipality of Itapuã d'Oeste. It presents an area of approximately $221.891,48$ ha, of which $90 \%$ are covered by Open Tropical Rain Forest RADAMBRASIL [3].

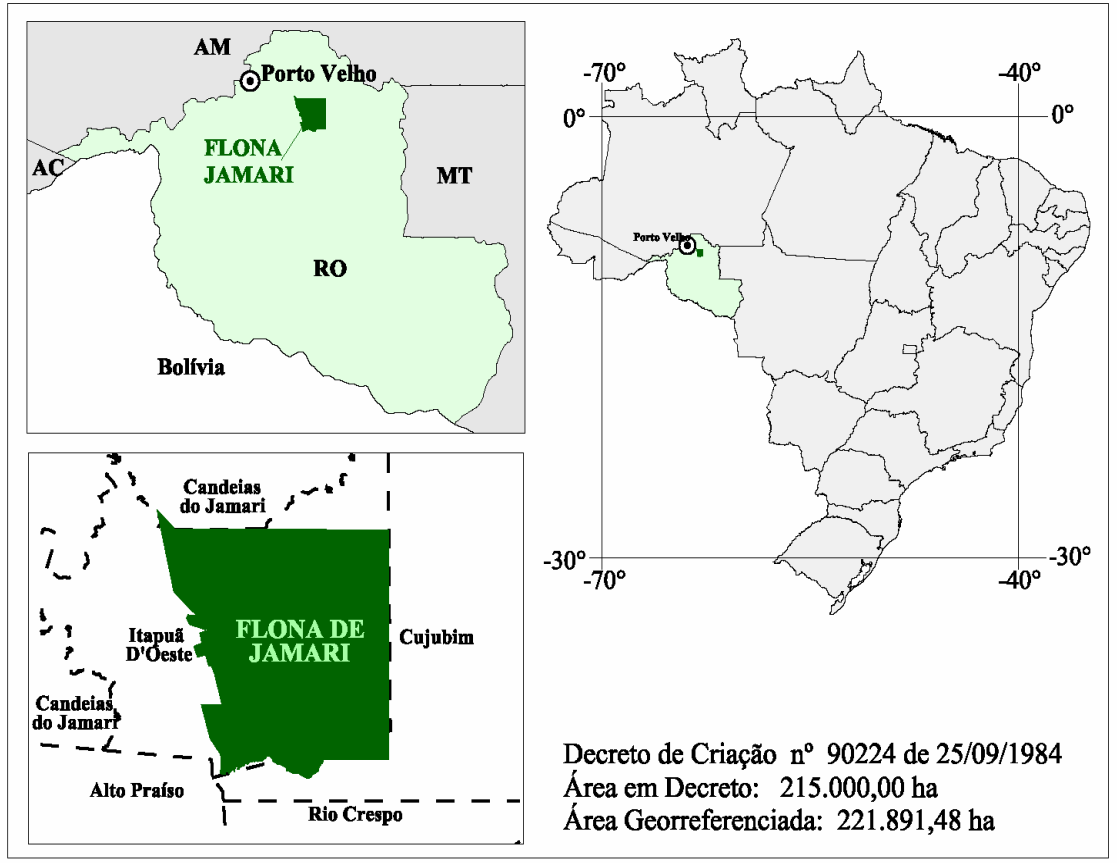

Figure 1: Location of the national forest (FLONA) of Jamari/RO (IBAMA).

In the surroundings of the area selected for study, the Rhodic Ferrasol and Xanthic Ferrasol (EMBRAPA [4] and França [5]) are predominant, being that the sampling was accomplished in Rhodic Ferrasol, in accordance with a previous survey. The climate of the region is hot and wet, with average temperature of $24^{\circ} \mathrm{C}$, presenting an annual precipitation of $2550 \mathrm{~mm}$, having its maximum in the months from December to March. The relative humidity is around 80 to $85 \%$, there being a clearly defined dry season with its most critical period between July and August.

Since the beginning of the 1970s, tin has been exploited in the National Forest of Jamari, and these activities have been creating degraded areas that are being now recovered. The disturbed areas possess surfaces that range from 5 to 140 ha.

The recovery strategies are based on the soil preparation for three consecutive years, making use of terrain remodeling practices, soil conservation techniques, 
planting of legumes (green fertilizer), chemical fertilizing and liming, on the planting of native forest species and on the monitoring of the soil, the vegetation and the fauna throughout this entire period.

The samples were collected superficially, with the help of an auger, in the layer between $0-20 \mathrm{~cm}$, in regular intervals of 20 meters, totalizing 4 samples composed by an area located between the UTM coordinates latitude 0900 '00" to $930^{\prime} 00^{\prime \prime S}$ and longitude $624^{\prime} 4^{\prime} 05^{\prime \prime}$ to 63 16'54"W, containing forest, fallow vegetation, mining floor, dry tailing and sandy tailing. The types of terrain, recovery strategies and levels are found on Table 1 .

Table 1: Description of areas and recovery strategies.

\begin{tabular}{|c|c|c|c|c|}
\hline Treatment & Area & Type of terrain & Recovery strategies & $\begin{array}{c}\text { Recover } \\
\text { levels }\end{array}$ \\
\hline $\mathrm{T} 1$ & April 14th & Mining floor & $\begin{array}{c}5 \text { years of seedlings } \\
\text { planting } \\
\text { (no soil preparation) }\end{array}$ & N5 \\
\hline $\mathrm{T} 2$ & April 14th & Tailing & $\begin{array}{l}1 \text { year of seedlings } \\
\text { planting } \\
\text { (with soil preparation) }\end{array}$ & N4 \\
\hline $\mathrm{T} 3$ & April 14th & White tailing & $\begin{array}{l}1 \text { year of seedlings } \\
\text { planting } \\
\text { (with soil preparation) }\end{array}$ & N4 \\
\hline $\mathrm{T} 4$ & $\begin{array}{l}\text { Novo } \\
\text { mundo }\end{array}$ & $\begin{array}{l}\text { Washing plant } \\
\text { tailing }\end{array}$ & $\begin{array}{c}3 \text { years of soil } \\
\text { preparation }\end{array}$ & N3 \\
\hline T5 & $\begin{array}{l}\text { Serra da } \\
\text { Cacimba }\end{array}$ & Mining floor & $\begin{array}{c}2 \text { years of soil } \\
\text { preparation }\end{array}$ & $\mathrm{N} 2$ \\
\hline T6 & Poço B & Mining floor & $\begin{array}{l}3 \text { years of soil } \\
\text { preparation }\end{array}$ & N3 \\
\hline $\mathrm{T} 7$ & $\begin{array}{c}\text { Serra da } \\
\text { Onça }\end{array}$ & Mining floor & $\begin{array}{l}3 \text { years of seedlings } \\
\text { planting } \\
\text { (with soil preparation) }\end{array}$ & N3 \\
\hline $\mathrm{T} 8$ & $\begin{array}{c}\text { Serra da } \\
\text { Onça }\end{array}$ & Mining floor & $\begin{array}{l}2 \text { years of seedlings } \\
\text { planting } \\
\text { (with soil preparation) }\end{array}$ & N5 \\
\hline T9 & $\begin{array}{l}\text { Serra da } \\
\text { Onça }\end{array}$ & Tailing & $\begin{array}{c}3 \text { years of soil } \\
\text { preparation }\end{array}$ & N3 \\
\hline $\mathrm{T} 10$ & $\begin{array}{c}\text { Fallow } \\
\text { vegetation }\end{array}$ & Preserved soil & Testimony & NF \\
\hline T11 & Mata & Preserved soil & Testimony & $\mathrm{NF}$ \\
\hline $\mathrm{T} 12$ & $\begin{array}{l}\text { Santa } \\
\text { Maria }\end{array}$ & Tailing & $\begin{array}{c}3 \text { years of soil } \\
\text { preparation }\end{array}$ & N3 \\
\hline $\mathrm{T} 13$ & $\begin{array}{l}\text { Santa } \\
\text { Maria }\end{array}$ & Mining floor & $\begin{array}{c}1 \text { year of seedlings } \\
\text { planting } \\
\text { (with soil preparation) }\end{array}$ & N4 \\
\hline
\end{tabular}

The samples for biological analysis were conditioned in ice until the moment of analysis. The soil analyses were conducted in the Department of Technology of UNESP, in the Jaboticabal campus. 
The analyses of carbon and nitrogen of the microbial biomass were conducted according to the method proposed by Vance et al. [6] and that of the dehydrogenase activity through the method described in Casida et al. [7].

\section{Results and discussion}

Below are presented results obtained with the monitoring of some soil parameters. In Figure 2 are the nitrogen and carbon values from samples collected in the 13 treatments described in Table 1.

As it is possible to observe, the areas that went through the 3 years of soil preparation, mainly (T6), had values close to those found in the fallow vegetation (T10), in terms of both carbon and nitrogen. The worst results were those observed in the area called Santa Maria.

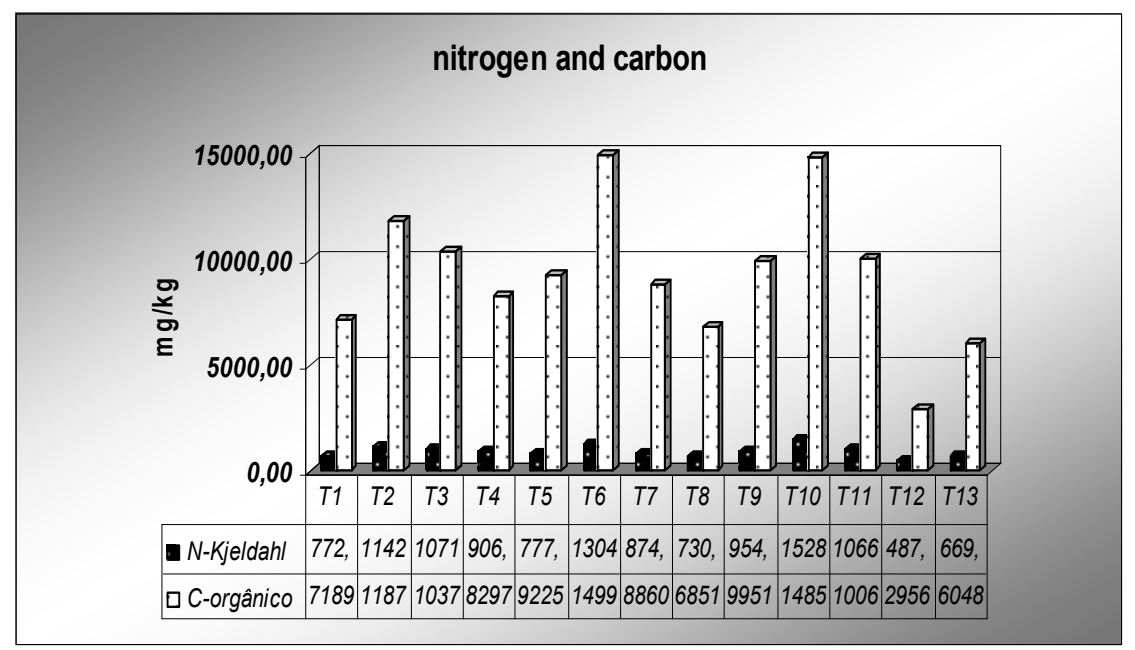

Where: T1= April 14th - mining floor- 5 years, T2 = April 14th - tailing - 1 year of seedlings planting, T3= April 14th - white tailing -1 year of seedlings planting, T4 = Novo Mundo (WP) washing plant -3 years of soil preparation, T5= Serra da Cacimba - Mining floor -2 years of soil preparation, T6 = Poço B - Mining floor - 3 years of soil preparation, T7 = Serra da Onça - Mining floor - 3 years of seedlings planting, T8 = Serra da Onça - Mining floor - 2 years of seedlings planting, T9 = Serra da Onça - tailing - 3 years of soil preparation, T10 = Fallow vegetation - Serra da Onça, T11 = Mata - Serra da Onça Mata , T12 = Santa Maria - tailing vermelho - 3 years of soil preparation, T13 = Santa Maria - mining floor -1 year of seedlings planting.

Figure 2: Nitrogen and carbon in soil samples.

Similar results were observed for the carbon and nitrogen of the microbial biomass (BMC and BMN) (Figure 3), being that $\mathrm{T} 6$ and $\mathrm{T} 2$ have presented the highest values, mainly for the $\mathrm{BMC}$, and these treatments suffered interventions and soil preparation for three consecutive years, applying the proposed methodology. The values of carbon microbial biomass indicate the reserve potential of this element that participates in the process of humidification, while 


\section{C-biomass and $\mathrm{N}$-biomass}

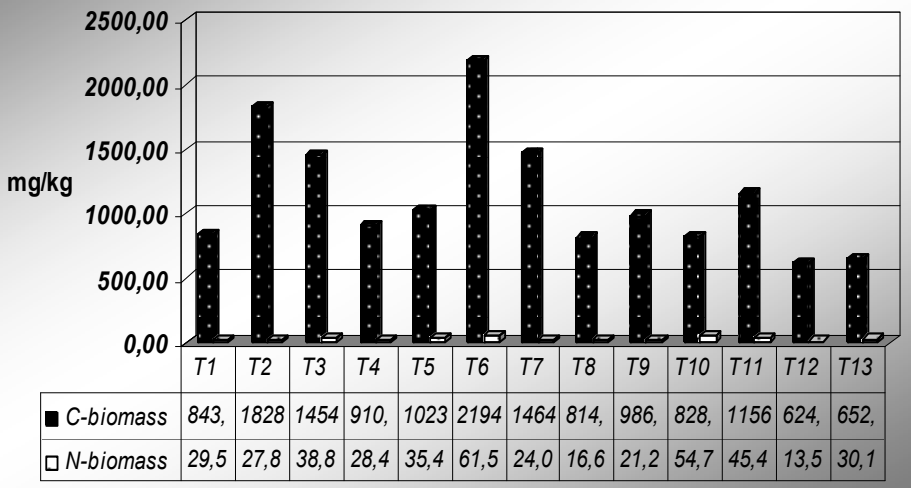

Where: T1 = April 14th - mining floor- 5 years, T2 = April 14th - tailing - 1 year of seedlings planting, T3= April 14th - white tailing -1 year of seedlings planting, T4 = Novo Mundo (WP) washing plant -3 years of soil preparation, T5= Serra da Cacimba - Mining floor - 2 years of soil preparation, T6 = Poço B - Mining floor - 3 years of soil preparation, T7 = Serra da Onça - Mining floor - 3 years of seedlings planting, T8 = Serra da Onça - Mining floor - 2 years of seedlings planting, T9 = Serra da Onça - tailing - 3 years of soil preparation, T10 = Fallow vegetation - Serra da Onça, T11 = Mata - Serra da Onça Mata , T12 = Santa Maria - tailing vermelho - 3 years of soil preparation, $\mathrm{T} 13$ = Santa Maria - mining floor -1 year of seedlings planting.

Figure 3: Carbon and nitrogen of the biomass in soil samples.

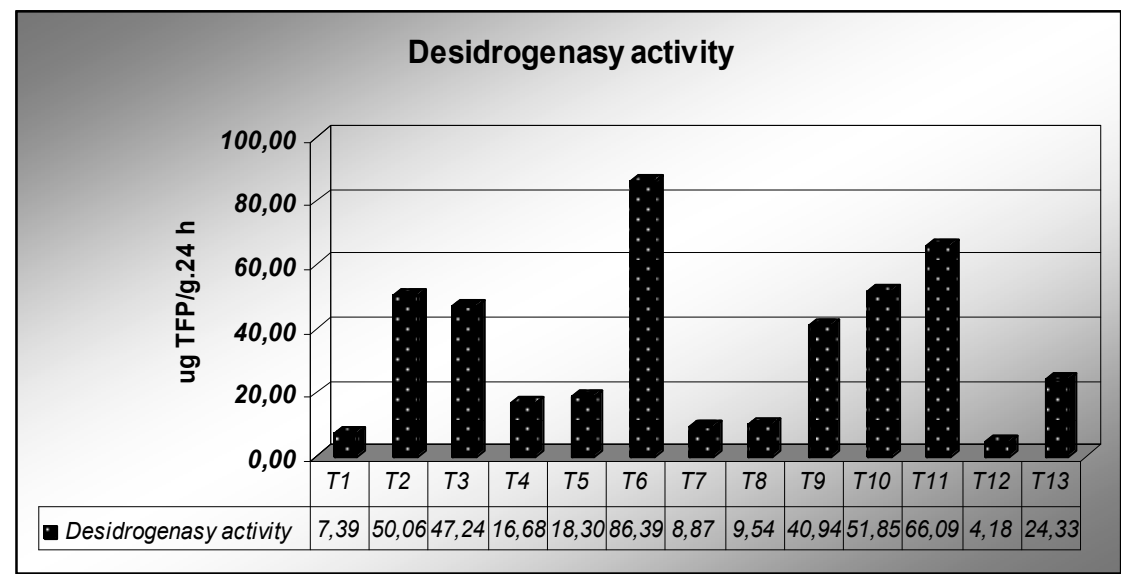

Where: T1 = April 14th - mining floor- 5 years, T2 = April 14th - tailing - 1 year of seedlings planting, T3= April 14th - white tailing -1 year of seedlings planting, T4 = Novo Mundo (WP) washing plant -3 years of soil preparation, T5= Serra da Cacimba - Mining floor -2 years of soil preparation, T6 = Poço B - Mining floor - 3 years of soil preparation, T7 = Serra da Onça - Mining floor - 3 years of seedlings planting, T8 = Serra da Onça - Mining floor - 2 years of seedlings planting, T9 = Serra da Onça - tailing - 3 years of soil preparation, T10 = Fallow vegetation - Serra da Onça, T11 = Mata - Serra da Onça Mata , T12 = Santa Maria - tailing vermelho - 3 years of soil preparation, T13 = Santa Maria - mining floor - 1 year of seedlings planting.

Figure 4: Dehydrogenase activity in soil samples. 
the nitrogen microbial biomass $(\mathrm{BMN})$ estimates the nitrogen reserve that may be reabsorbed by the plants (Gama-Rodrigues et al. [8]). Thus, according to the results obtained and in agreement with the results observed by Longo et al. [9] regarding the microbial biomass, it is possible to observe that the soil preparation provided a significant increase in the BMC, especially after three years of planting. As for the BMN, this planting still has not been enough to promote alterations in the soil/substract. Similar results were observed for the dehydrogenase activity (Figure 4).

In many degraded areas what we find is not soil anymore, but only a mineral matrix, of poor physical structure, little or no organic matter and a very small amount of nutrients for the plants. If the vegetable coverage can be established, it will initiate the soil formation process through chemical, physical and biological alterations of the soil, promoted by the rhizospheric activity of the roots. This way, the establishment of plants in degraded areas promotes the increment of $\mathrm{C}$ $\mathrm{CO}_{2}$ in the soil via photosynthesis, favoring the action of microorganisms that will contribute to the formation of root symbioses, promoting the improvement in the nutritional state and the tolerance of the host plant to the stress conditions it is under (Siqueira [10]). The accumulation and cycling of $\mathrm{N}$ are the most important factors to the development of vegetation in degraded areas in natural or artificial colonization (Coppin and Bradshaw [11]).

In Figures 5 and 6, it is possible to observe some aesthetic advances that took place in the mining floor and white tailing areas, in the locations called Serra da Onça and April 14th.

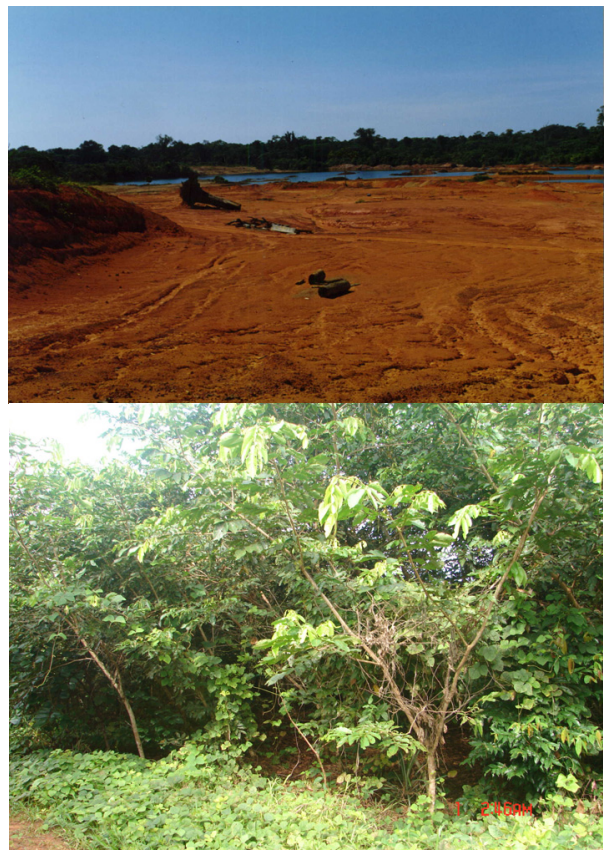

Figure 5: Mining "Serra da Onça" - mining floor. 


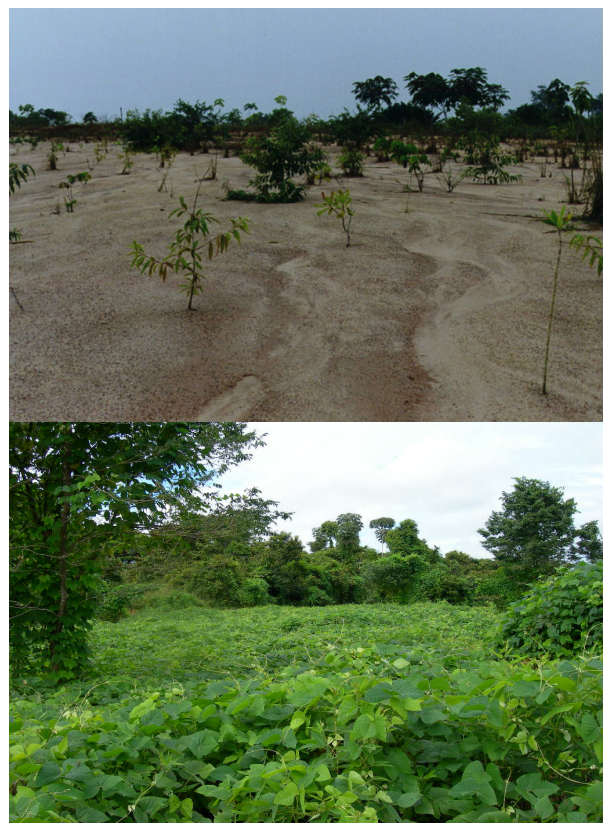

Figure 6: Mining “April $14^{\text {th }}$ " - white tailing.

\section{Final consideration}

The analysis of some parameters that are being used in the monitoring program of the recovering areas revealed that the soil preparation, respecting the three years proposed in the methodology, is very important for the success of the recovery program. Some of the areas analyzed already present some parameters with values close or superior to the ones found in the fallow vegetation, which is the testimony area.

\section{Acknowledgements}

To Fundação de Amparo a Pesquisa do Estado de São Paulo (FAPESP), the BRASCAN and to the Brazilian Institute of the Environment and Mineral Resources you Renewed (IBAMA).

\section{References}

[1] Fontes, M.P.F. Estudo pedológico reduz impacto da mineração. Revista da Cetesb de Tecnologia. AMBIENTE, São Paulo, p. 58-61, 1991.

[2] Franco, A.A., Campelo, E.F.C., Dias, L.E., Faria, S.M. de. Revegetação de solos degradados: Seropédica, Brasília, EMBRAPA-CNPBS, 1992, 8p. (EMBRAPA-CNPBS. Comunicado Técnico, 9). 
[3] RADAMBRASIL. Folha SC-20. Porto Velho. Rio de Janeiro: Departamento Nacional de Produção Mineral, 1978. 661p. (Levantamento de Recursos Naturais, 16).

[4] EMBRAPA. Centro Nacional de Pesquisa de Solos (Rio de Janeiro, RJ). Sistema brasileiro de classificação de solos. Brasília: Embrapa produção de Informação, Rio de Janeiro, 1999. 412p.

[5] França, J.T. Estudos da sucessão secundária em áreas contíguas a mineração de cassiterita na Floresta Nacional do Jamari-RO. 1991. 169p. Dissertação (Mestrado) ESALQ/USP. Piracicaba.

[6] Vance, E.D., Brookes, P.C., Jenkinson, A.S. Na extraction method for measuring soil microbial biomass C. Soil Biologic Biochemical, oxford, v.19, p.703-707, 1982.

[7] Casida, L.E., Klein, D. A. Jr, Santoro, T. Soil dehydrogenase activity. In: Weaver R.W. et al. (Ed.) Methods of soil analysis: microbiological and biochemical properties. Madison: ASA/SSA, 1964, p. 775-883.

[8] Gama-Rodrigues, da E.F., Gama-Rodrigues, da A.C., Barros de N.F. Biomassa microbiana de carbono e nitrogênio de solos sob diferentes coberturas florestais. In: Congresso Brasileiro de Ciência do Solo, Viçosa, 1995.

[9] Longo, R.M., Melo, W.J., Ribeiro, A.I., Melo, G.P. Avaliação da biomassa microbiana e atividade da desidrogenase em solo minerado na região amazônica após a introdução da adubação verde. In... Anais Simpósio de Recuperação de áreas degradadas, outubro de 2006.

[10] Siqueira, J.O. Microrganismos e processos biológicos do solo: perspectiva ambiental. Empresa Brasileira de Pesquisa Agropecuária, Centro Nacional de Pesquisa de Arroz e Feijão; Centro Nacional de Pesquisa de Soja. Brasília: EMBRAPA-SPI, 1994. 142p - (EMBRAPA-CNPAF. Documentos, 45).

[11] Coppin, N.J. \& Bradshaw, D. Quarry Reclamation - The Establishment of Vegetation in Quarries and open Pit Non-metal Mines. University of Liverpool, 1982. 